Dept of Animal Diseases,

Faculty of Veterinary Medicine,

Hama, Al-Baath University, Syria.

\title{
CHARACTERIZATION OF SYRIAN ISOLATES OF AVIAN INFECTIOUS LARYNGOTRACHEITIS VIRUS BY RESTRICTION FRAGMENT LENGTH POLYMORPHISM
}

(With 2 Tables and 4 Figures)

\author{
By \\ M.Y. ARNAOUT; M.M. FADEL and I.M. MOHRA*
}

*Dept. of Animal Production, Faculty of Agriculture, Damascus University, Syria.

(Received at 15/9/2010)

صفات العزولات السورية لفيروس التهاب الحنجرة والرغامى المعدي الطيري عن الترفي

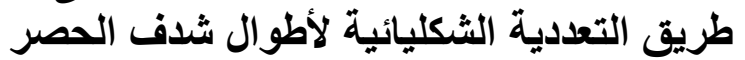

ماهر باسبين الأرناؤوط ، محد مصطفى فاضل ، إبراهيم محد مهرة

عرّف مرض التهاب الحنجرة و الر غامى المعدي في معظم بلدان العالم و لا بز ال يشكل تهديداً

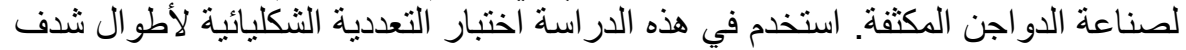

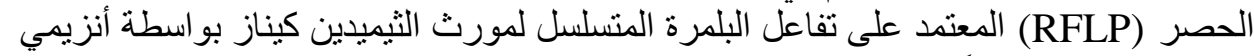

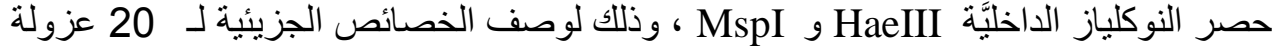

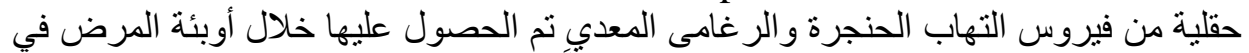

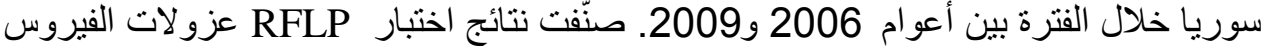

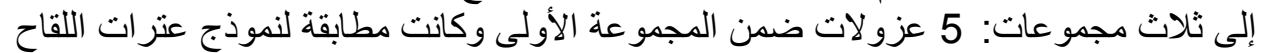

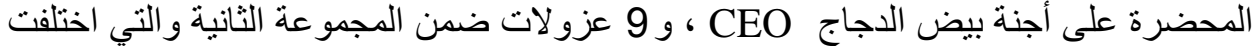

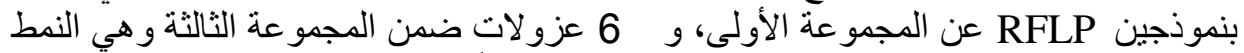

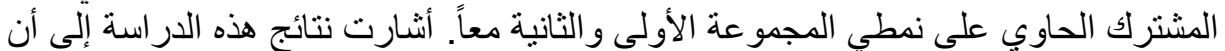

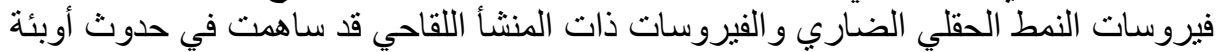
مرض التهاب الحنجرة و الرغامى المعدي في قطعان الدجاج في سوريا.

\section{SUMMARY}


Avian Infectious Laryngotracheitis (ILT) has been identified in most countries around the world and remains a threat to the intensive poultry industry (Guy and Bagust, 2003). In this study, polymerase chain reaction and restriction fragment length polymorphism (PCR-RFLP) of thymidine kinase (TK) gene using restriction endonucleases HaeIII and MspI was utilized to characterize 20 field isolates of ILTV obtained from different chicken flocks during ILT outbreaks in Syria between 2006 and 2009. Combinations of PCR-RFLP patterns classified the ILT virus isolates into three groups. Five isolates were categorized as group I that had identical pattern to the two chicken embryo origin CEO vaccine strains. Nine isolates were categorized as group II that differed in two RFLP patterns from CEO vaccine strains, whereas six isolates categorized as group III that contained a mixture pattern of group I and group II patterns. The results of this study indicated that both wild type and vaccine derived viruses were involved in ILT field cases in Syria.

Key words: Infectious Laryngotracheitis virus, Polymerase chain reaction, Restriction fragment length polymorphism.

\section{INTRODUCTION}

Avian infectious laryngotracheitis (ILT) is a highly contagious acute respiratory disease of chickens that is caused by Gallid herpesvirus 1 (family Herpesviridae). Sever forms of infections are characterized by severe respiratory signs, expectoration of bloody mucus and high mortality, while mild respiratory signs, mucoid tracheitis and low mortality are described in mild forms of infections (Guy and Bagust, 2003). Laryngotracheitis virus has been identified in most countries and remains a serious disease wherever susceptible poultry populations occur, especially in large numbers (Biggs, 1982).

More recently, DNA detection by conventional polymerase chain reaction (PCR) or real-time PCR have become the methods of choice for virus diagnosis (Villarreal et al., 2004; Creelan et al., 2006; Callison et al., 2007; Chacon et al., 2007; Crespo et al., 2007). 
Differentiation of LTV strains of varying virulence, particularly wild-type and modified live-vaccine viruses, is an important practical problem (Guy and Bagust, 2003). The differentiation between field and vaccine strains has been demonstrated through the use of PCR coupled with restriction fragment length polymorphism (RFLP) of the viral genes $\mathrm{gG}$, TK, ICP4, $\mathrm{gC}$ and $\mathrm{gM} / \mathrm{UL} 9$ and have been described for epidemiological investigations (Graham et al., 2000; Kirkpatrick et al., 2006; Neff et al., 2008; Oldoni et al., 2008). In Syria, numerous cases of ILTV were observed and diagnosed (Arnaout, 2005; Arnaout et al., 2009), but it doesn't know whether such cases are related to vaccine strains or wild type viruses of ILTV. The objective of the present study was to characterize 20 field isolates of ILTV collected from different poultry farms in Syria by using RFLP-PCR of Thymidine kinase (TK) gene to investigate the variety of the strains.

\section{MATERIALS and METHODS}

\section{Viruses}

A total of 20 field isolates of ILTV collected between February 2006 and June 2009 were analyzed. Four field isolates were obtained from previous study (Arnaout et al., 2009) and the other isolates were obtained during the course of this study. Nineteen out of 20 isolates were obtained from different commercial chicken flocks and one isolate were from a backyard flock. The viruses compared in present study were isolated from natural outbreaks of ILT in Syria. All isolates were propagated during acute phase of the disease by inoculation on the chorioallantoic membrane (CAM) of SPF embryonated chicken eggs according to OIE virus isolation procedures of ILTV (OIE, 2008). Two commercial ILT CEO vaccines, Nobilis ILTV Serva strain (Lot/A011BJ01, Intervet, Boxmeer, The Netherlands) and Fowl Laryngotracheitis Vaccine (Lot/54354, Lohmann, Animal Health, Winslow, Maine, USA), were used in this study. 
Table 1: Details of ILTV isolates used in this study.

\begin{tabular}{|l|c|l|c|c|}
\hline Isolate ID & Date of field case & Vaccination & Origin & Mortality \% \\
\hline BH & $26 / 02 / 2006$ & Non-vaccinated & Layer & 10 \\
\hline A2 & $05 / 03 / 2006$ & Non-vaccinated & Layer & 5 \\
\hline A1 & $12 / 04 / 2006$ & CEO vaccine & Layer & 29 \\
\hline TW & $08 / 06 / 2006$ & Non-vaccinated & Layer & 5 \\
\hline B1 & $16 / 05 / 2007$ & Non-vaccinated & Layer & 16 \\
\hline GZ & $25 / 09 / 2007$ & Non-vaccinated & Broiler Breeder & 10 \\
\hline ZZ & $23 / 11 / 2007$ & CEO vaccine & Broiler Breeder & 2 \\
\hline A001 & $02 / 01 / 2008$ & Non-vaccinated & Broiler Breeder & 30.77 \\
\hline D3311 & $20 / 01 / 2008$ & Non-vaccinated & Broiler Breeder & 25 \\
\hline CM991 & $12 / 02 / 2008$ & Non-vaccinated & Broiler Breeder & 1.5 \\
\hline F25-3 & $25 / 03 / 2008$ & Non-vaccinated & Broiler & $*$ \\
\hline Backyard & $25 / 03 / 2008$ & Non-vaccinated & Backyard & $*$ \\
\hline F1-4 & $01 / 04 / 2008$ & CEO vaccine & Broiler & $*$ \\
\hline L921 & $25 / 01 / 2009$ & Non-vaccinated & Layer & 24 \\
\hline F4-2 & $04 / 02 / 2009$ & Non-vaccinated & Broiler & $*$ \\
\hline PX1 & $04 / 02 / 2009$ & CEO vaccine & Layer & 1 \\
\hline CC2 & $17 / 03 / 2009$ & CEO vaccine & Layer & 1 \\
\hline MJ1 & $19 / 03 / 2009$ & CEO vaccine & Layer & 1 \\
\hline MJ2 & $19 / 03 / 2009$ & CEO vaccine & Layer & 1 \\
\hline XLM & $05 / 06 / 2009$ & CEO vaccine & Layer & 1.5 \\
\hline & & & 10 \\
\hline
\end{tabular}

* Increased mortality but the data is not available accurately

\section{Extraction of viral DNA}

DNA was extracted using commercial DNA extraction kit (PeqGOLD DNA Tissue Mini, lot/07016, Germany) according to the manufacturer. Briefly, $25 \mathrm{ul}$ of protease was added to $250 \mathrm{ul}$ aliquots of supernatants from homogenized CAMs, then $250 \mathrm{ul}$ of lysis buffer BL was added, and the mixture incubated at $70{ }^{\circ} \mathrm{C}$ for $10 \mathrm{~min}$. The protein free DNA was precipitated with 260 ul of $100 \%$ ethanol. The solution was transferred to $\mathrm{HiBind} \circledast$-DNA column and centrifuged at $8000 \mathrm{rpm}$ for 1 min. Two washings steps were performed, and the DNA was eluted with 50 ul elution buffer and stored at 70- C. 


\section{Polymerase Chain Reaction of TK gene}

PCR was performed using PCR commercial kit (Lot/133194470, HotStarTaq Master mix kit, Qiagen, Germany). Each amplification reaction was performed in a $50 \mathrm{ul}$ volume, containing $25 \mathrm{ul}$ HotStarTaq ${ }^{\circledR}$ Master mix 2x, 0.5 um of each primer, 15 ul RNase free water and 5ul of DNA template. The primers utilized in this study were selected from previously published work (Neff et al., 2008). The primers were used to amplify a 2.1 $\mathrm{kb}$ fragment of the ILTV genome containing the TK gene. The primers were TK gene (sense) 5-GCTGGGCTAAATCATCCAAG-3 and TK gene (antisense) 5-GGAAGCGGAACATTACGAAC-3. The reaction mixture was incubated in thermal cycler (Techne, England) at $95{ }^{\circ} \mathrm{C}$ for $15 \mathrm{~min}$, then subjected to 35 cycles of $94{ }^{\circ} \mathrm{C}$ for $1 \mathrm{~min}, 56^{\circ} \mathrm{C}$ for $1 \mathrm{~min}$, and $72{ }^{\circ} \mathrm{C}$ for $2 \mathrm{~min}$, then finally incubated at $72{ }^{\circ} \mathrm{C}$ for $10 \mathrm{~min}$. PCR products were separated by electrophoresis in $1.5 \%$ agarose gel (Agarose, Genkam, Germany) in 1X TAE buffer stained with ethidium bromide $(5 \mathrm{ul} / 100 \mathrm{ml})$ and visualized under UV illuminator.

\section{RFLP}

PCR products were purified post-amplification using the QIAquick PCR purification Kit (Lot/133198423, Qiagen, Germany) according to manufacturer. Ten ul of purified PCR products were digested separately with 10 unit of restriction enzyme HaeIII and MspI (NewEngland biolab, USA), 2 ul of enzyme buffer and 2 ul of distilled water. DNA fragments were separated by electrophoresis $(3 \mathrm{~V} / \mathrm{cm}$ for $2 \mathrm{hr})$ in $2 \%$ agarose gel.

\section{RESULTS}

\section{PCR and RFLP}

$2.1 \mathrm{kbp}$ PCR product was successfully amplified from all field viruses and the two commercial ILT vaccine. Some of positive samples are presented in Fig 1. No bands were seen in negative controls.

Restriction digestion of TK using HaeIII gave pattern A and pattern $B$ and mixture pattern $A+B$ (Fig 3 and $4 b$ ). Pattern A consisted of four bands approximately of 104, 146, 851, $954 \mathrm{bp}$ while pattern B consisted of five bands 104, 146, 367, 484, 954 .

Restriction digestion of TK using MspI gave pattern A and pattern $B$ and mixture pattern $\mathrm{A}+\mathrm{B}$ (Fig 3 and 4a). Pattern A consisted of five patterns 119, 140, 250, 588, 966 bp while pattern B consisted of six bands $119,140,192,255,390,966$. 


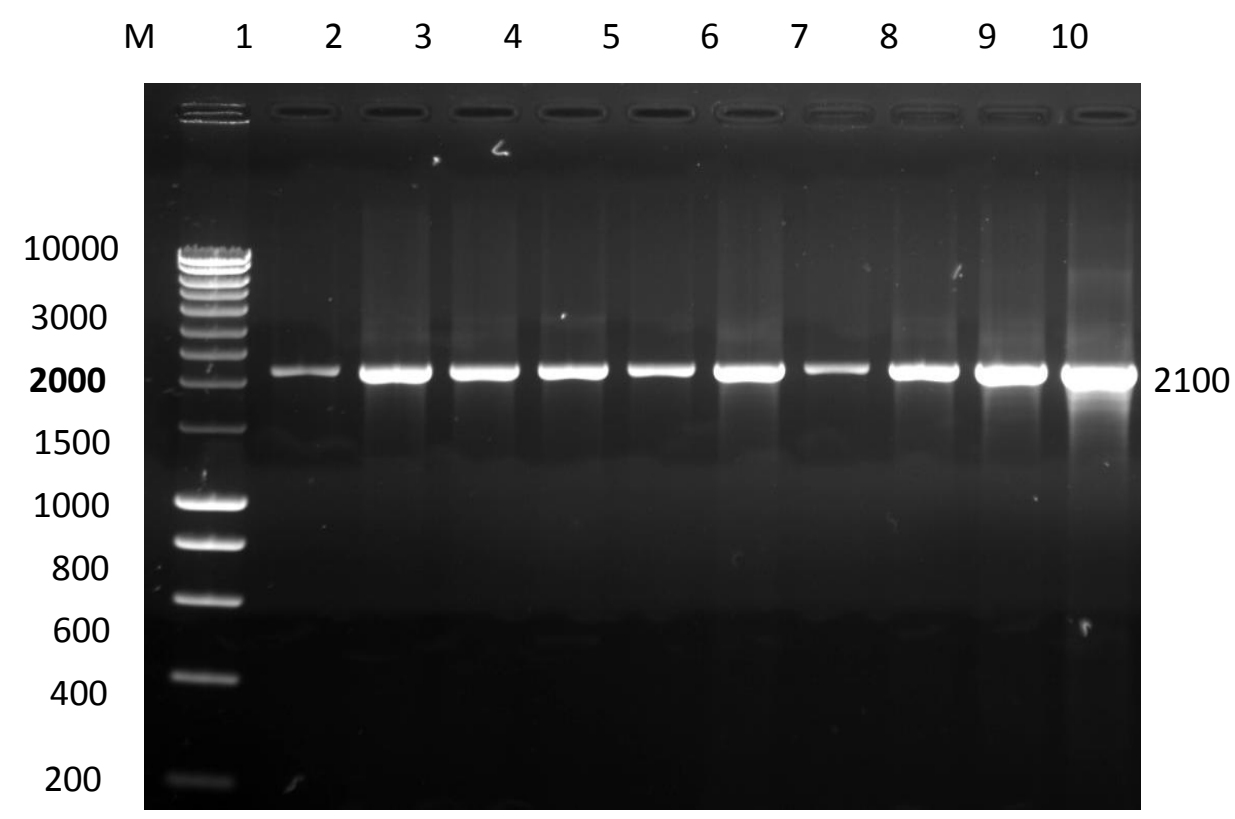

Fig. 1: $\mathrm{M}=$ Smart Ladder 200-10000 bp, 1= L921, 2=TW, 3=GZ, 4= A2, 5= CM991, $6=\mathrm{D} 3311,7=\mathrm{ZZ}, 8=\mathrm{BH}, 9=\mathrm{MJ} 2,10=\mathrm{A} 001$.

$\begin{array}{lllllllllll}M & 1 & 2 & 3 & 4 & 5 & 6 & 7 & 8 & 9 & 10\end{array}$

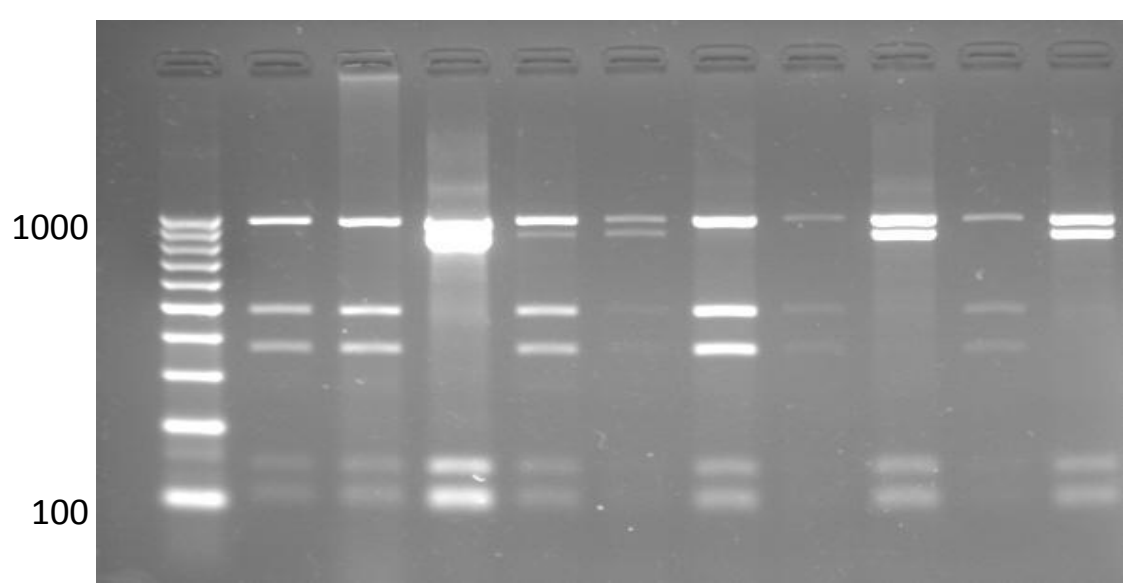

Fig. 2: (RFLP-TK-HaeIII): $M=100 \mathrm{bp}$ marker, $1=\mathrm{TW}, 2=\mathrm{BH}$, 3= Lohmann Vaccine, 4= F25-3, 5= ZZ, 6= D3311, 7= Backyard1, 8= XLM, 9= L921, 10= PX1. 


$\begin{array}{lllllllllll}M & 1 & 2 & 3 & 4 & 5 & 6 & 7 & 8 & 9 & 10\end{array}$

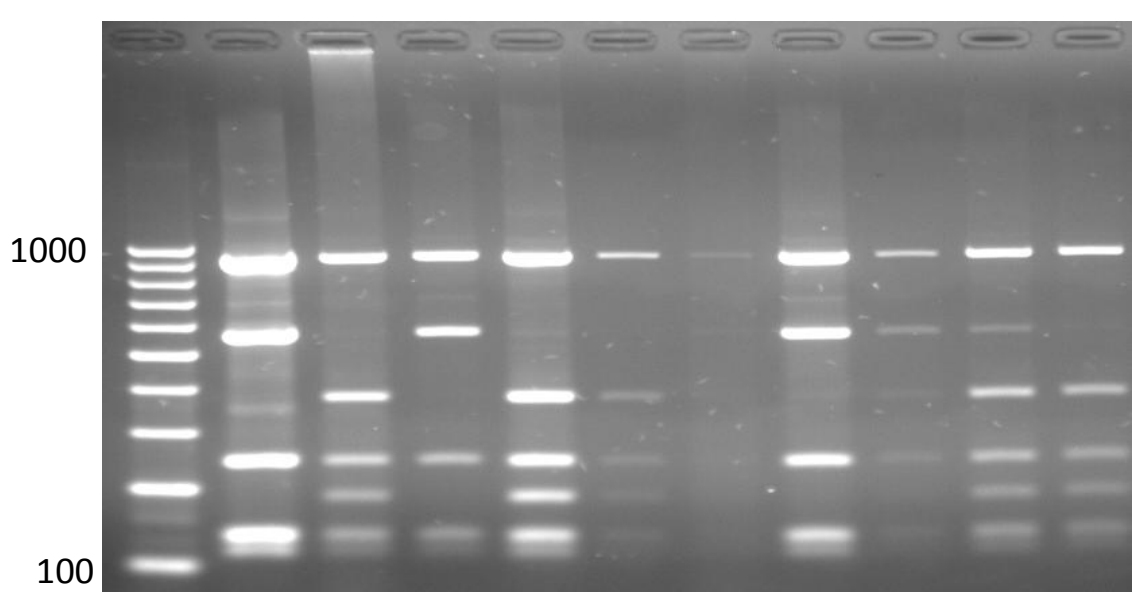

Fig. 3: (RFLP- TK-MspI): $M=100$ bp marker, $1=$ Lohmann Vaccine, $2=$ $\mathrm{BH}, 3=$ Serva vaccine $, 4=\mathrm{D} 3311,5=\mathrm{L} 921,6=$ Backyard1, 7= $\mathrm{XLM}, 8=\mathrm{ZZ}, 9=\mathrm{F} 25-3,10=\mathrm{TW}$.

A

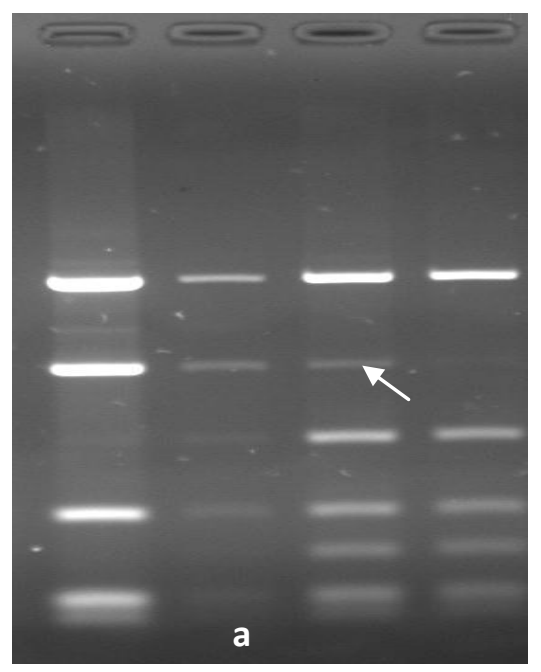

B

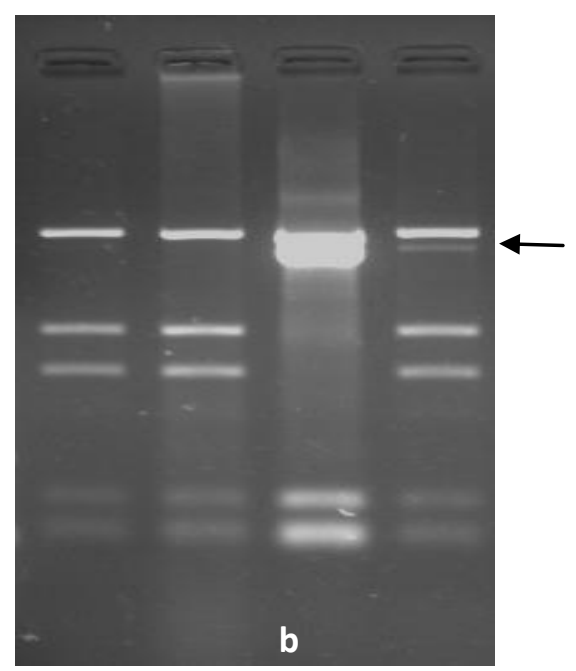

Fig. 4: $(\mathbf{a})=\mathrm{TK}-\mathrm{MspI}$ : pattern A (CEO vaccine type), pattern $\mathrm{B}$ (wild type) and pattern $\mathrm{AB}$ (Mixture type); (b) = TK -HaeIII: pattern A (CEO vaccine type), pattern $B$ (wild type) and pattern $A B$ (Mixture type). 
Table 2: RFLP analysis of $2.1 \mathrm{~kb}$ TK of ILTV field isolates and vaccine strains

\begin{tabular}{|c|c|c|c|c|}
\hline Isolate / Strain & MspI & HaeIII & Pattern combination & RFLP Group \\
\hline Lohmann Vaccine & A & A & AA & I \\
\hline Intervet Vaccine & A & A & AA & I \\
\hline PX1 & A & A & AA & I \\
\hline $\mathrm{CC} 2$ & A & A & AA & I \\
\hline MJ2 & A & A & AA & I \\
\hline XLM & A & A & AA & I \\
\hline F4-2 & A & A & AA & I \\
\hline $\mathrm{BH}$ & B & B & $\mathrm{BB}$ & II \\
\hline TW & B & B & BB & II \\
\hline B1 & $\mathrm{B}$ & B & $\mathrm{BB}$ & II \\
\hline GZ & B & B & $\mathrm{BB}$ & II \\
\hline A001 & B & B & $\mathrm{BB}$ & II \\
\hline D3311 & B & B & $\mathrm{BB}$ & II \\
\hline CM991 & B & B & $\mathrm{BB}$ & II \\
\hline Backyard1 & B & B & BB & II \\
\hline L921 & B & B & $\mathrm{BB}$ & II \\
\hline $\mathrm{A} 2$ & $\mathrm{AB}$ & $\mathrm{AB}$ & $\mathrm{ABAB}$ & III \\
\hline A1 & $\mathrm{AB}$ & $\mathrm{AB}$ & $\mathrm{ABAB}$ & III \\
\hline $\mathrm{ZZ}$ & $\mathrm{AB}$ & $\mathrm{AB}$ & $\mathrm{ABAB}$ & III \\
\hline F1-4 & $\mathrm{AB}$ & $\mathrm{AB}$ & $\mathrm{ABAB}$ & III \\
\hline F $25-3$ & $\mathrm{AB}$ & $\mathrm{AB}$ & $\mathrm{ABAB}$ & III \\
\hline MJ1 & $\mathrm{AB}$ & $\mathrm{AB}$ & $\mathrm{ABAB}$ & III \\
\hline
\end{tabular}

\section{DISCUSSION}

Several molecular assays have been developed to distinguish between wild type and vaccine viruses. Recently, RFLP based on PCR was used successfully in the differentiation of ILT viruses (Oldoni and Garcia, 2007). This approach has been utilized in several countries to characterize 
circulating field strains (Graham et al., 2000; Creelan et al., 2006; Kirkpatrick et al., 2006; Ojkic et al., 2006).

The TK gene is associated with ILTV virulence, and previous studies have demonstrated that differentiation between virulent and vaccine-like field strains can be achieved through RFLP and sequence analysis of this region (Han and Kim, 2001a+b; Neff et al., 2008).

In this study, PCR-RFLP of TK gene was used to examine 20 Syrian field isolates of ILTV. Previous similar study indicated that the same region of the TK gene through RFLP with HaeIII restriction enzyme enabled to distinguish between European isolates of ILTV (Neff et al., 2008). In our results, RFLP of TK gene with HaeIII and MspI divided all the isolates into three groups. Five isolates $(25 \%)$ belonged to group I which had identical RFLP patterns to CEO vaccine strains. These isolates except (F1-4) were obtained from vaccinated flocks that had a history of respiratory signs and low mortality with having been vaccinated approximately 5-10 days before this isolation. These findings suggests more likely that these isolates originated from re-isolation of vaccine strains.

Nine isolates (45\%) belonged to group II which had different RFLP patterns from vaccine strains. All these isolates were obtained from unvaccinated flocks that had high mortality. This result indicated that wild type viruses differed from vaccine viruses of ILT have recently been circulating in poultry farms in Syria; Also the circulation of wild type viruses may explain the high mortality in unvaccinated affected chicken flocks. More comprehensive about the virulence of these wild type viruses may be obtained by pathogenicity studies in chickens.

Six isolates (30\%) belonged to group III (mixture type). Three out of these 6 isolates were obtained from unvaccinated flocks, which indicate to co-infection between wild type and vaccine derived viruses. The co-infection with both types of ILTV in field cases was also reported in the USA (Oldoni et al., 2008).

These results demonstrated that RFLP based on TK described herein distinguished between wild type and vaccine type of Syrian ILTV isolates. In summary, present data indicate that both "wild-type" and vaccine viruses are involved in ILT cases in Syria, but the origin of the "wildtype" virus remains unknown. Both types of viruses were detected in vaccinated and unvaccinated flocks, and although genetically different as confirmed by PCR-RFLP analysis. 


\section{REFERENCES}

Arnaout, M. (2005): Serological Study of Infectious Laryngotracheitis in Chickens in Syria. (M. SC. Thesis). Veterinary Medicine Faculty, University of AL-Baath, Syria, pp 175.

Arnaout, Y.M.; Fadel, M.M. and Mohra, M.I. (2009): Isolation and Molecular Detection of Infectious Laryngotracheitis Virus in Layers and Broiler Breeders in Syria. Assuit Veterinary Medical Journal. 55, 123: 243-254.

Biggs, P.M. (1982): The World of Poultry Disease. Avian Pathology., 11: 281-300.

Callison, S.A.; Riblet, S.M.; Oldoni, I.; Sun, S.; Zavala, G.; Williams, S.; Ressurreccion, R.; Spackman, E. and Garcia, M. (2007): Development and Validation of a Real-Time Taqman PCR Assay for The Detection and Quantification of Infectious Laryngotracheitis Virus in Poultry. Journal of Virological Methods., 139: 31-38.

Chacon, J.L.; Brandao, P.E.; Villarreal, L.Y.; Gama, N.M. and Ferreira, A.J. (2007): Survey of Infectious Laryngotracheitis Outbreak in Layer Hens and Differential Diagnosis with Other Respiratory Pathogens. Brazilian Journal of Poultry Science., 9: 61-67.

Creelan, J.L.; Calvert, V.M.; Graham, D.A. and McCullough, S.J. (2006):

Rapid Detection and Characterization from Field Cases of Infectious Laryngotracheitis Virus by Real-Time Polymerase Chain Reaction and Restriction Fragment Length Polymorphism. Avian Pathology., 35: 173-179.

Crespo, R.; Woolcock, P.R.; Chin, R.P.; Shivaprasad, H.L. and Garcia, M. (2007): Comparison of Diagnostics Techniques in an Outbreak of Infectious Laryngotracheitis from Meat Chickens. Avian Diseases., 51: 858-862.

Graham, I.E.; McLaren, V.; Calvert, D.; Torrens and Meehan, B.M. (2000): RFLP Analysis of Recent Northern Ireland Isolates of Infectious Laryngotracheitis Virus: Comparison with Vaccine Virus and Field Isolates from England, Scotland And The Republic Of Ireland. Avian Pathology., 29: 57-62.

Guy, J.S. and Bagust, T.J. (2003): Laryngotracheitis. In. Saif Y.M.; Barnes, H.J.; Glisson, J.R.; Fadley, A.M.; Mc Dougald, L.R. \& Swayne, D. E. (Eds.), Diseases of Poultry, 11th edn (pp. 121 -134). Ames: Iowa State Press. United States. 
Han, M.G. and Kim, S.J. (2001a): Analysis of Korean Strains of Infectious Laryngotracheitis Virus by Nucleotide Sequences and Restriction Fragment Length Polymorphism. Veterinary Microbiology., 83: 321-331.

Han, M.G. and Kim, S.J. (2001b): Comparison of Virulence and Restriction Endonuclease Cleavage Patterns of Infectious Laryngotracheitis Viruses Isolated in Korea. Avian Pathology., 30: 337-344.

Kirkpatrick, N.C.; Mahmoudian, A.; Colson, C.A; Devlin, J.M. and Noormohammad, A.H. (2006): Relationship between Mortality, Clinical Signs and Tracheal Pathology in Infectious Laryngotracheitis. Avian Pathology., 35: 449-453.

Neff, C.; Sudler, C. and Hoop, R.K. (2008): Characterization of Western European Field Isolates and Vaccine Strains of Avian Infectious Laryngotracheitis Virus by Restriction Fragment Length Polymorphism and Sequence Analysis. Avian Diseases., 52: 278-283.

Office International des Epizooties (OIE) (2008): Avian Infectious Laryngotracheitis. Terrestrial Manual., page 456-463.

Ojkic, D.; Swinton1, J.; Vallieres, M.; Martin, E.; Shapiro, J.; Sanei, B. and Binnington1, B. (2006): Characterization of Field Isolates of Infectious Laryngotracheitis Virus From Ontario. Avian Pathology., 35: 286-292.

Oldoni, I. and Garcia, M. (2007): Characterization of Infectious Laryngotracheitis Virus Isolates from The US by Polymerase Chain Reaction and Restriction Fragment Length Polymorphism of Multiple Genome Regions. Avian Pathology., 36: 167-176.

Oldoni, I.; Rodriguez-Avila, A.; Riblet, S. and Garcia, M. (2008): Characterization of Infectious Laryngotracheitis Virus (ILTV) Isolates from Commercial Poultry by Polymerase Chain Reaction and Restriction Fragment Length Polymorphism (PCR-RFLP). Avian Diseases., 52: 59-63.

Villarreal, L.Y.; Brandão, P.E.B.; Chacón, J.L.V.; Doretto, J.L.; Ito, N.; Gama, N.S.; Ishizuka, M.M.; Luchese, A.; Buchala, F.A.; Ferreira, A.C.S. and Ferreira, A.J.P. (2004): Detection and Molecular Characterization of Infectious Laryngotracheitis Virus in Laying Hens in Brazil. Brazilian Journal of Poultry Science., 6: 253-256. 
Assiut Vet. Med. J. Vol. 56 No. 127 October 2010 